\title{
Persepsi Mahasiswa PGSD UKI Toraja terkait STEAM
}

\author{
Trivena ${ }^{1}$, Weryanti Laen Langi' ${ }^{2}$ \\ ${ }^{1}$ (Pendidikan Guru Sekolah Dasar, Fakultas Keguruan dan Ilmu Pendidikan/Universitas Kristen Indonesia \\ Toraja, Indonesia) \\ ${ }^{2}$ (Pendidikan Guru Sekolah Dasar, Fakultas Keguruan dan IImu Pendidikan/Universitas Kristen Indonesia \\ Toraja, Indonesia) \\ * Corresponding Author. E-mail: $\underline{\text { trivena@ukitoraja.ac.id }}$
}

Receive: $13 / 08 / 2021$

Accepted: 23/09/2021

Published: 01/10/2021

\begin{abstract}
Abstrak
Penelitian ini bertujuan untuk mengidentifikasi persepsi mahasiswa Pendidikan Guru Sekolah Dasar terkait STEAM. Jenis penelitian yang akan digunakan dalam penelitian adalah jenis penelitian deskriptif kualitatif. Intrumen yang digunakan pada pengumpulan data berupa kuesioner mahasiswa yang terdiri dari 4 item pertanyaan dengan jawaban pilihan ganda dan 48 item pernyataan dengan menggunakan skala Likert. Data yang diperoleh berupa data kuesioner yang diberikan kepada 100 mahasiswa semester V PGSD UKI Toraja dan diperoleh 93 kueisoner yang diisi dan dikembalikan oleh responden. Setelah itu, peneliti menganalisis data yang telah dikumpulkan dari lapangan. Hasil penelitian menunjukkan bahwa rata-rata mahasiwa baru pertama kali mendengar istilah STEAM dan hanya mengenal mata kuliah di bidang STEAM secara terpisahpisah. Persepsi mahasiswa PGSD UKI Toraja terhadap STEAM dari segi sikap, pendapat dan lingkungan sudah cukup baik. Motivasi dan keyakinan mahasiswa terhadap mata kuliah di bidang STEAM sudah nampak. Mahasiswa juga cukup tertarik belajar pada mata kuliah di bidang STEAM dan berpikir bahwa mata kuliah tersebut tidak terlalu sulit. Mahasiswa PGSD juga setuju bahwa pengetahuan yang didapatkan pada mata kuliah yang terkait STEAM mampu membantu dalam pengembangan karir sebagai guru ke depan. Sedangkan dari aspek lingkungan, persepsi mahasiswa positif bahwa kurikulum, fasilitas, orangtua/kerabat dan dosen cukup mendukung dalam pembelajaran yang terkait STEAM.
\end{abstract}

Kata Kunci: STEAM, Persepsi, Mahasiswa PGSD

\begin{abstract}
This study aims to identify the perceptions of primary school teacher education students regarding STEAM. The type of research used in research is a qualitative-descriptive type of research. A questionnaire, consisting of 4 question items with multiple-choice answers and 48 statement items using a Likert scale. The collected data was transmitted in the form of questionnaire data to 100 students in the fifth semester of the Primary School Teacher Education UKI Toraja. The researcher then analyzed the data that had been collected. The results showed that, on average, students heard the term STEAM for the first time and only knew courses in the field of STEAM separately. The perception of the students towards STEAM regarding attitudes, opinions, and the environment is good. The students' motivation and belief to take courses in the STEAM area are already visible. The students are also very interested in studying STEAM courses and do not find these courses too difficult. The students also agree that the knowledge acquired in STEAM can help in developing a future career as a teacher. From an environmental point of view, however, the student's perception is positive that the curriculum, the facilities, the parents/relatives, and the lecturers strongly support STEAM learning.
\end{abstract}

Keywords: STEAM, Perception, Primary School Teacher Education Students 


\section{Pendahuluan}

STEM merupakan kepanjangan dari Science Technology Engineering and Mathematics (Costantino \& Costantino, 2017) yang kemudian mengalami perkembangan dengan penambahan "Art" sehingga sekarang dikenal menjadi STEAM (Clarke, 2018). Pembelajaran dengan berbasis STEAM yang menempatkan konsep sains dan matematika dalam konteks rekayasa, teknologi dan seni mampu menuntun peserta didik dalam mengembangkan kemampuan HOTS (High Order Thingking Skills), pemecahan masalah atau problem solving skills dan kreativitas (Komaruddin, 2016).

Sains sendiri merupakan suatu kajian ilmiah tentang alam semesta dan peristiwa yang terjadi di dalamnya yang melalui metode-metode ilmiah dan penalaran sehingga dapat ditarik sebuah kesimpulan (Snow \& Dibner, 2016). Teknologi secara sederhana memiliki pengertian suatu alat yang memudahkan atau membantu manusia dalam melakukan aktivitasnya (Rusman, 2012). Engineering merupakan rekayasa atau pengetahuan tentang mendesain atau menciptakan sebuah produk yang di dalamnya memuat cara pemecahan masalah dan matematika merupakan suatu ilmu yang mempelajari pola dan hubungan yang menjadi bahasa bagi sains, teknologi dan engineering dalam pembelajaran STEM (Firman, 2016). Sedangkan penambahan Árt pada STEM diharapkan mampu menumbuhkan kreativitas dan inovasi peserta didik lewat karya yang dihasilkan sesuai dengan imajinasinya namun tetap aktual dan jelas (Wulandari et al., 2020).

Salah satu penelitian terdahulu terkait STEAM yang dilakukan oleh Khairani, dkk. pada tahun 2018 yang dipublikasikan pada UJMES dengan judul "Pembelajaran STEM dalam Perkuliahan Kalkulus di Perguruan Tinggi" menemukan bahwa dengan mengintegrasikan Sains, Teknologi, dan Rekayasa membuat pembelajaran kalkulus lebih dapat disesuaikan serta dapat digunakan sesuai dengan masing-masing jurusan (Khairani et al., 2018). Penelitian terkait STEM juga pernah dilakukan oleh Maria, dkk. dengan judul "Membangun Kemampuan Berpikir Kreatif
Matematis Siswa dengan Pembelajaran PjBL terintegrasi STEM" yang dipublikasikan pada tahun 2019 pada Prosiding Seminar Nasional Pascasarjana UNNES menemukan bahwa STEM yang dipadukan dalam pembelajaran $\mathrm{PjBL}$ mampi meningkatkan minat siswam membuat pembelajaran lebih bermakna dan meningkatkan kemampuan problem solving siswa dan menjadi tantangan sekaligus motivasi siswa karena menumbuhkan kreativitas siswa (Maria et al., 2019). Hasil penelitian tersebut sejalan dengan penelitian yang dilakukan oleh Adrianus Zega bahwa pembelajaran menggunakan model PjBL membuat mahasiswa lebih memahami pembelajaran terutama yang menuntut adanya proyek (Zega, 2021).

Kedua hasil penelitian ini juga didukung oleh Primasari, dkk dalam penelitiannya di tahun 2019 yang berjudul "Science Technology Engineering and Mathematics (STEM) pada pembelajaran IPA di SMP yang menemukan bahwa pembelajaran IPA dengan mengintegrasikan STEM efektif dalam meningkatkan hasil belajar siswa dengan gain sebesar 0,4 (kategori sedang) (Prismasari et al., 2019). Selain itu hasil penelitan terkait STEM yang pernah dilakukan oleh penulis sebelumnya pada siswa SD dengan judul "Fifth Grade Elementary School Perception of STEM" ditemukan bahwa rata-rata siswa SD tertarik mempelajari mata pelajaran terkait STEM khususnya Matematika dan IPA walaupun belum menjadi mata pelajaran favorit (Trivena et al., 2018).

Dari beberapa penelitian terdahulu di atas dapat disimpulkan bahwa pembelajaran dengan berbasis atau mengintegrasikan STEM di dalamnya memiliki efek yang positif terhadap perkembangan kemampuan peserta didik. Namun, penulis belum menemukan penelitian terkait dengan STEM yang dilakukan pada mahasiswa PGSD dengan memadukan Art di dalamnya dengan tujuan dapat menjadi bahan penelitian dan pertimbangan prodi dalam pengembangan desain mata kuliah berbasis STEAM.

Selain itu STEAM menjadi salah satu bahan kajian penting dalam penyusunan kurikulum yang dikembangkan oleh Himpunan 
Dasar Pendidikan Guru Sekolah Dasar seIndonesia (HD-PGSDI) yang menjadi rekomendasi dalam penyusunan kurikulum PGSD seluruh Indonesia (-, 2020). Dimana nantinya diharapkan mahasiswa PGSD mampu memiliki keterampilan abad ke-21 yang dikenal dengan kompetensi 4C bahkan sudah mengalami pengembangan menjadi 6C (critical thinking, collaboration. communication, creativity, computational logic dan compassion) agar mampu bersaing secara global dalam mengahadapi tantangan abad ke-21 dan Revolusi Industri 4.0 (Fikri et al., 2020). Akan tetapi berdasarkan observasi awal yang dilakukan khususnya pada Rencana Perkuliahan Semester (RPS) dosen pengampu mata kuliah di PGSD UKI Toraja, belum ada satupun mata kuliah yang memuat tentang STEAM. Selain itu beberapa penelitian terdahulu juga lebih banyak meneliti terkait STEM-nya saja dengan subyek penelitian lebih sering pada siswa SMP dan SMA (Khairani et al., 2018; Maria et al., 2019; Prismasari et al., 2019).

Sehingga peneliti merasa tertarik dan perlu melakukan penelitian dengan tujuan untuk mengidentifikasi persepsi mahasiswa PGSD UKI Toraja terkait STEAM dengan harapan dapat menjadi bahan kajian untuk penelitian selanjutnya dan dapat menjadi pertimbangan prodi dalam mengembangkan bahan kajian STEAM yang dapat dituangkan dalam Capaian Pembelajaran Mata Kuliah (CPMK) atau desain pembelajaran pada rumpun mata kuliah yang erat kaitannya dengan STEAM seperti IPA, Teknologi Pendidikan, Matematika dan SPdB.

\section{Metode}

Jenis penelitian yang akan digunakan oleh penulis adalah jenis penelitian deskriptif dengan pendekatan kualitatif. Menurut Arikunto, penelitian deskriptif adalah penelitian yang dilakukan untuk menyelidiki keadaan, kondisi atau hal lain-lain tanpa memberi perlakuan terhadap objek atau wilayah yang diteliti lalu kemudian dipaparkan dalam bentuk laporan penelitian (Arikunto, 2013). Intrumen yang digunakan pada pengumpulan data berupa kuesioner mahasiswa yang terdiri dari 4 item pertanyaan dengan jawaban pilihan ganda dan 48 item pernyataan. Kuesioner tersebut menggunakan skala Likert dengan pilihan jawaban Sangat Tidak Setuju (STS) dengan skor 1, Tidak Setuju (TS) dengan skor 2, Netral (N) dengan skor 3, Setuju (S) dengan skor 4 dan Sangat Setuju (SS) dengan skor 5. Data yang diperoleh berupa data kuesioner yang diberikan kepada 100 mahasiswa semester V PGSD UKI Toraja dan diperoleh 93 kueisoner yang diisi dan dikembalikan oleh responden. Setelah itu, peneliti melanjutkan ke tahapan berikutnya yaitu menganalisis data yang telah dikumpulkan dari lapangan.

\section{Hasil dan Pembahasan}

Adapun hasil dan pembahasan penelitian adalah sebagai berikut:

Instrumen yang digunakan untuk mengukur persepsi mahasiswa PGSD UKI Toraja Semester V yaitu berupa kuesioner yang terdiri dari 4 item petanyaan dengan jawaban pilihan ganda untuk melihat persepsi awal mahasiswa terkait STEAM. Sedangkan 48 item pernyataan dengan menggunakan skala likert yang kemudian dianalisis dengan menghitung skor perolehan angket kemudian dikategorikan ke 3 aspek persepsi yang dilihat dari segi sikap, pendapat dan lingkungan yang mendukung pembelajaran STEAM (Trivena et al., 2018). Berdasarkan data tersebut maka hasil persepsi mahasiswa PGSD UKI Toraja disajikan pada tabel 1 di bawah ini:

Tabel 1. Hasil Persepsi Mahasiswa PGSD UKI Toraja terkait STEAM dari Segi Sikap, Pendapat dan Lingkungan

\begin{tabular}{|c|c|c|c|}
\hline $\begin{array}{c}\text { Indikat } \\
\text { or }\end{array}$ & $\begin{array}{c}\text { Sub- } \\
\text { Indikat } \\
\text { or }\end{array}$ & $\begin{array}{l}\text { Nomor } \\
\text { Item }\end{array}$ & $\begin{array}{c}\text { Persenta } \\
\text { se }(\%)\end{array}$ \\
\hline \multirow[t]{2}{*}{ Sikap } & $\begin{array}{l}\text { Motiva } \\
\text { si }\end{array}$ & $\begin{array}{c}3,24,25 \\
26,27\end{array}$ & 71,53 \\
\hline & $\begin{array}{l}\text { Kesiapa } \\
\text { n/Keya } \\
\text { kinan }\end{array}$ & $\begin{array}{c}7,8,33,4 \\
4\end{array}$ & 86,69 \\
\hline \multicolumn{3}{|c|}{ Rata-rata $(\%)$} & 79,11 \\
\hline \multirow[t]{3}{*}{$\begin{array}{l}\text { Pendap } \\
\text { at }\end{array}$} & $\begin{array}{l}\text { Keterta } \\
\text { rikan }\end{array}$ & $\begin{array}{c}1,5,9,21 \\
, 35,45\end{array}$ & 70,04 \\
\hline & $\begin{array}{l}\text { Kesulit } \\
\text { an }\end{array}$ & $\begin{array}{c}2,4,6,34 \\
, 46 \\
\end{array}$ & 78,96 \\
\hline & $\begin{array}{l}\text { Pengem } \\
\text { bangan } \\
\text { Karir }\end{array}$ & $\begin{array}{l}13,17,1 \\
8,19,20\end{array}$ & 76,97 \\
\hline
\end{tabular}




\begin{tabular}{|c|c|c|c|}
\hline & & $\begin{array}{c}, 21,22, \\
23 \\
, 39,40,4 \\
1,42,43 \\
, 47,48\end{array}$ & \\
\hline \multicolumn{3}{|c|}{ Rata-rata (\%) } & 75,32 \\
\hline \multirow[t]{4}{*}{$\begin{array}{l}\text { Lingku } \\
\text { ngan }\end{array}$} & $\begin{array}{l}\text { Kurikul } \\
\text { um }\end{array}$ & 10 & 74,19 \\
\hline & $\begin{array}{l}\text { Fasilita } \\
\mathrm{S}\end{array}$ & 12 & 71,18 \\
\hline & $\begin{array}{l}\text { Orangt } \\
\text { ua dan } \\
\text { Kerabat }\end{array}$ & $\begin{array}{l}14,16,2 \\
8,29,30, \\
31,32,3 \\
6,37,38\end{array}$ & 70,51 \\
\hline & Dosen & 11,15 & 69,78 \\
\hline \multicolumn{3}{|c|}{ Rata-rata $(\%)$} & 71,42 \\
\hline
\end{tabular}

Setelah mendapatkan persentase rata-rata dari setiap indikator aspek selanjutnya dilakukan pengkategorian skor dengan mengacu pada tabel 2. berikut:

Tabel 2. Kategori Persentase Skor Persepsi Mahasiswa

\begin{tabular}{|c|c|}
\hline $\begin{array}{c}\text { Rentang } \\
\text { Persentase } \\
(\%)\end{array}$ & Kategori \\
\hline $0-20$ & Sangat Tidak Setuju \\
\hline $21-40$ & Tidak Setuju \\
\hline $41-60$ & Netral \\
\hline $61-80$ & Setuju \\
\hline $81-100$ & Sangat Setuju \\
\hline
\end{tabular}

\section{Persepsi awal mahasiswa terkait STEAM}

Untuk mengetahui persepsi awal mahasiswa ada 4 item pertanyaan berupa pilihan ganda yang diberikan. Berdasarkan keempat pertanyaan tersebut diperoleh hasil bahwa sebagian besar mahasiswa Semester V PGSD UKI Toraja baru pertama kali mengenal STEAM. Sedangkan yang sudah pernah mendengar atau mengenal istilah STEAM, pada umumnya hanya mendengar dari guru dan teman atau membaca istilah STEAM di media sosial. Selanjutnya untuk mata kuliah terkait STEAM sendiri yaitu IPA, Komputer, Matematika dan Seni (Hoachlander \& Yanofsky, 2011), mahasiswa lebih banyak menyukai mata kuliah di bidang Seni dan Bahasa dan paling sedikit memilih mata kuliah di bidang Matematika dan IPA yang merupakan dua mata pelajaran yang sering dikombinasikan dalam pembelajaran STEAM (Breiner et al., 2012; Sanders, 2009; Wang et al., 2011). Hal inilah yang menyebabkan kebanyakan siswa atau mahasiswa tidak bisa menguasai matematika dan IPA karena pada dasarnya untuk menguasai mata pelajaran atau mata kuliah di bidang tersebut dibutuhkan minat dan motivasi yang cukup untuk membangkitkan usaha dalam belajar matematika ataupun IPA (Gafoor \& Kurukkan, 2017; Ng et al., 2016). Hasil penelitian juga menunjukkan bahwa sebagian besar pemilihan atau dalam meprogram mata kuliah, mahasiswa dipengaruhi oleh dosennya dibanding keputusan dari dirinya sendiri.

\section{Persepsi mahasiswa dari aspek sikap terhadap pembelajaran STEAM}

Sikap baik itu motivasi dan keyakinan dalam pembelajaran STEAM harus diperhatikan (Zollman, 2012).Dari segi sikap mahasiswa terhadap STEAM terdapat 2 indikator yang diukur yaitu motivasi dan kesiapan mahasiswa terhadap pembelajaran STEAM pada lingkup mata kuliah di program studi PGSD. Berdasarkan tabel 1 dapat dilihat bahwa dari aspek sikap diperoleh hasil persepsi mahasiswa sebesar $79,11 \%$ dan jika dikategorikan maka rata-rata siswa setuju terhadap item-item kuesioner terkait sikap mahasiswa terhadap STEAM.

Pada indikator motivasi mahasiswa terhadap pembelajaran STEAM, rata-rata mahasiswa menjawab setuju dimana hasil persentase sebesar 71,53\%. Hasil tersebut menunjukkan bahwa dalam hal memotivasi dirinya sendiri dalam belajar terkait STEAM sudah nampak pada mahasiswa, misalnya menekuni mata kuliah terkait STEAM, gemar membaca buku, menonton acara dokumenter, mengunjungi pameran sains dan berpartisipasi dalam lomba/kegiatan yang berkaitan dengan STEAM.

Sedangkan dari indikator kesiapan dan keyakinan mahasiswa terhadap pembelajaran terkait STEAM diperoleh rata-rata sebesar $86,69 \%$ yang berarti bahwa rata-rata mahasiswa merasa siap dan yakin terhadap mata kuliah di bidang STEAM pada prodi PGSD. Selain itu, mahasiswa tidak hanya siap dan percaya diri 
terhadap pembelajaran STEAM di prodi PGSD tetapi juga merasa peduli terhadap pengembangan mata kuliah berbasis STEAM, hal tersebut nampak pada prestasi mahasiswa yang cukup baik pada mata kuliah yang terkait STEAM. Hal tersebut sejalan dengan penelitian sebelumnya yang menunjukkan bahwa kepercayaan diri dan kecemasan dalam mata pelajaran di bidang STEAM seperti matematika memiliki pengaruh kuat terhadap prestasi belajar di mata pelajaran tersebut (Liu, 2008).

\section{Persepsi mahasiswa dari aspek pendapat terhadap pembelajaran STEAM}

Pendapat mahasiswa terhadap pembelajaran STEAM di prodi PGSD dilihat dari segi ketertarikan, kesulitan dan pengembangan karir di bidang STEAM. Berdasarkan tabel 1 di atas, rata-rata persepsi mahasiswa dari aspek pendapat terhadap pembelajaran STEAM sebesar 75,32\% atau berada pada kategori setuju.

Dari segi ketertarikan, sebesar 70,04\% ketertarikan mahasiswa terhadap mata kuliah di bidang STEAM. Hal ini dikarenakan di persepsi awal mahasiswa memang sebagian besar memilih mata kuliah seni dan bahasa menjadi mata kuliah yang paling diminati dibandingkan dengan mata kuliah terkait STEAM seperti mata kuliah pada rumpun Matematika dan IPA. Ketertarikan siswa ataupun mahasiswa terhadap suatu mata pelajaran atau mata kuliah dipengaruhi oleh banyak faktor, salah satunya metode pembelajaran guru atau dosen. Penelitian sebelumnya menyatakan bahwa pembelajaran di bidang STEAM khususnya Matematika dan IPA tidak menarik dikarenakan guru ataupun dosen lebih sering mendikte peserta didik dibanding melaksanakan pembelajaran langsung atau berbasis penemuan (inquary learning) untuk mata pelajaran atau mata kuliah di bidang IPA. Inquary learning yang diterapkan dalam pembelajaran di dalam kelas telah terbukti mampu merangsang minat atau ketertarikan peserta didik dalam pembelajaran dikarenakan dimulai dari menumbuhkan rasa ingin tahu peserta didik lewat bertanya, bereksplorasi, merencanakan, membangun pengetahuan yang baru dan merefleksikan apa yang sudah dipelajarinya (Chen \& Howard, 2010).
Untuk kesulitan mahasiswa yaitu sebesar $78,96 \%$ artinya bahwa rata-rata mahasiswa merasa tidak terlalu sulit belajar mata kuliah di bidang STEAM. Pembelajaran pada mata kuliah di bidang STEAM seperti pada IPA dan Matematika sebaiknya menyenangkan dan dapat meningkatkan kognitif, efektif dan psikomotorik (Claassen \& Kammer, 1986).

$$
\text { Persepsi mahasiswa terhadap }
$$
pengembangan karir terkait STEAM berdasarkan hasil kuesioner yaitu sebesar 76,97\%. Mahasiswa setuju bahwa orang-orang yang menekuni bidang STEAM memiliki prestasi dan kesuksesan juga mampu memberikan sumbangsih di bidang masyarakat. Mahasiswa juga setuju bahwa pengetahuan yang diperoleh pada mata kuliah terkait STEAM yang diprogram pada prodi PGSD penting untuk pengembangan karir sebagai seorang guru. Meskipun pendekatan STEAM lebih difokuskan pada kesiapan peserta didik dalam menghadapi revolusi industri 5.0, namun revolusi industri ini juga berdampak pada dunia pendidikan dimana guru dituntut untuk memahami hal-hal yang terkait pengembangan industri tersebut dan mempunyai tugas dalam mengembangkan kemampuan 4C (Critical Thinking and Problem Solving, Creativity and Innovative Skills, Collaboration and Communication Skills) siswa sejak dini lewat kebiasaan menggunakan pembelajaran berbasis STEAM yang melibatkan hands-on activity (Triana et al., 2020; Verma \& McKinney, 2011).

\section{Persepsi mahasiswa dari aspek lingkungan yang mendukung pembelajaran STEAM}

Terdapat 4 indikator dalam mengukur persepsi mahasiswa terkait STEAM dari aspek lingkungan yaitu kurikulum, fasilitas, dosen dan orangtua/kerabat. Berdasarkan tabel 1 rata-rata persepsi mahasiswa terhadap STEAM dari aspek lingkungan yaitu sebesar $71,42 \%$ yang berarti bahwa faktor lingkungan cukup mendukung mahasiswa dalam pembelajaran mata kuliah yang terkait STEAM di prodi PGSD. Hal ini sejalan dengan penelitian sebelumnya yang menunjukkan bahwa sebagian faktor yang mempengaruhi persepsi peserta didik terkait engineering dan pencapaian pada STEAM adalah lingkup sosial yang terdiri dari orang tua, 
teman sebaya dan juga pendidik (Fralick et al., 2009; Woolley et al., 2010).

Tabel 1 menunjukkan rata-rata persepsi mahasiswa terhadap kurikulum prodi PGSD yang terkait dengan STEAM sebesar 74,19\%. Hal tersebut menunjukkan rata-rata mahasiswa siswa setuju bahwa kurikulum di prodi PGSD sudah terkait dengan STEAM. Dibutuhkan kajian terlebih dahulu terhadap kompetensi peserta didik sehingga STEAM mampu selaras dengan kurikulum yang berlaku pada suatu jenjang pendidikan (Anggraini \& Huzaifah, 2017).

Dari segi fasilitas, persepsi mahasiswa sebesar 71,18 yang berarti bahwa fasilitas di prodi PGSD cukup mendukung pembelajaran STEAM. Hanya saja belum digunakan secara maksimal dalam mendukung mata kuliah yang berkaitan dengan rumpun ilmu di bidang STEAM.

Sedangkan persepsi mahasiswa terkait dukungan orangtua/kerabat dalam pemilihan mata kuliah berbasis STEAM adalah sebesar $70.51 \%$. Artinya rata-rata mahasiwa setuju bahwa orangtua mendukung anaknya dalam memilih mata kuliah di bidang STEAM. Dukungan dari teman sebaya juga mendukung persepsi mahasiswa terhadap pembelajaran STEAM.

Hasil kuesioner persepsi mahasiswa mengenai dukungan dosen dalam pemilihan mata kuliah di bidang STEAM di prodi adalah sebesar $69,78 \%$. Hal tersebut menunjukkan bahwa dosen juga mengambil peranan dalam pemilihan mata kuliah mahasiswa di bidang STEAM. Guru ataupun dosen memiliki peranan penting terutama dalam pengembangan literasi STEAM peserta didik (Afifah \& Qomaria, 2018). Menurut Srikoom dkk, persepsi pendidik terhadap STEAM memiliki pengaruh terhadap prestasi belajar peserta didik (Srikoom et al., 2017).

\section{Simpulan}

Persepsi mahasiswa PGSD UKI Toraja terhadap STEAM dari aspek sikap, pendapat dan lingkungan sudah cukup baik. Motivasi dan kesiapan mahasiswa terhadap mata kuliah di bidang STEAM sudah nampak. Mahasiswa juga cukup tertarik belajar pada mata kuliah di bidang STEAM dan berpikir bahwa mata kuliah tersebut tidak terlalu sulit. Mahasiswa PGSD juga setuju bahwa pengetahuan yang didapatkan pada mata kuliah yang terkait STEAM mampu membantu dalam pengembangan karir sebagai guru ke depan. Sedangkan dari aspek lingkungan, persepsi mahasiswa positif bahwa kurikulum, fasilitas, orangtua/kerabat dan dosen cukup mendukung dalam pembelajaran yang terkait STEAM.

\section{Daftar Pustaka}

[1] -. (2020). Rekomendasi Capaian Pembelajaran dan Lulusan Mata Kuliah Pertukaran Mahasiswa Program Merdeka Belajar.

[2] Afifah, A., \& Qomaria, N. (2018). Persepsi Calon Guru Ipa Dan Matematika Terhadap Pembelajaran Berorientasi Stem. Natural Science Education ..., 266-275. https://ecoentrepreneur.trunojoyo.ac.id/nser/article/ view/4840

[3] Anggraini, F. I., \& Huzaifah, S. (2017). Implementasi STEM dalam pembelajaran IPA di Sekolah Menengah Pertama. Seminar Nasional Pendidikan IPA Tahun 2021, 1(1), 722-731. http://conference.unsri.ac.id/index.php/s emnasipa/article/view/738

[4] Arikunto, S. (2013). Prosedur Penelitian Suatu Pendekatan Praktik. PT. Rineka Cipta.

[5] Breiner, J. M., Harkness, S. S., Johnson, C. C., \& Koehler, C. M. (2012). What Is STEM? A Discussion About Conceptions of STEM in Education and Partnerships. School Science and Mathematics, 112(1), 3-11. https://doi.org/10.1111/j.19498594.2011.00109.x

[6] Chen, C. H., \& Howard, B. (2010). Effect of live simulation on middle school students' attitudes and learning toward science. Educational Technology and Society, 13(1), 133-139. https://www.jstor.org/stable/jeductechso ci.13.1.133 
[7] Claassen, D. E., \& Kammer, A. E. (1986). Effects of octopamine, dopamine, and serotonin on production of flight motor output by thoracic ganglia of Manduca sexta. Journal of Neurobiology, 17(1), 114.

https://doi.org/10.1002/neu.480170102

[8] Clarke, M. (2018). STEM to STEAM : Policy and Practice. In Earth and Environmental Science Earth and Environmental Science (R0) (pp. 223236).

[9] Costantino, T., \& Costantino, T. (2017). STEAM by another name: Transdisciplinary practice in art and design education. Art Education Policy Review, 2913(June), 1-7. https://doi.org/10.1080/10632913.2017.1 292973

[10] Fikri, A., Rahmawati, A., \& Hidayati, N. (2020). Persepsi Calon Guru PAI terhadap Kompetensi 6C dalam Menghadapi Era 4.0. Jurnal Ilmiah Prodi Pendidikan Agama Islam, 12(01), 89-96.

[11] Firman, H. (2016). Pendidikan STEM sebagai Kerangka Inovasi Pembelajaran Kimia untuk Meningkatkan Daya Saing Bangsa Dalam Era Masyarakat Ekonomi Asean. Prosiding Seminar Nasional Kimia Dan Pembelajarannya, September, 1-7.

[12] Fralick, B., Kearn, J., Thompson, S., \& Lyons, J. (2009). How middle schoolers draw engineers and scientists. Journal of Science Education and Technology, 18(1), 60-73. https://doi.org/10.1007/s10956-0089133-3

[13] Gafoor, A. K., \& Kurukkan, A. (2017). Need for Managing Mathematics Teaching Learning Process from an Affective Outcome Perspective. INSIGHT Journal of Applied Research in Education, 22(1), 53-63.

[14] Hoachlander, G., \& Yanofsky, D. (2011). Making STEM real: by infusing core academics with rigorous real-world work, linked learning pathways prepare students for both college and career.
Educational Leadership, 68(3), 60-65.

[15] Khairani, Mukhni, \& Ain, F. Q. (2018). Pembelajaran berbasis stem dalam perkuliahan kalkulus di perguruan tinggi. UJMES, 03, 104-111.

[15] Komaruddin, U. (2016). Penggunaan ebook berbasis STEM tema pesawat sederhana untuk meningkatkan penguasaan konsep dan technology engineering literacy siswa. UPI Bandung.

[16] Liu, F. (2008). Impact of Online Discussion on Elementary Teacher Candidates' Anxiety towards Teaching Mathematics. Education, 128(4), 614630.

http://search.ebscohost.com/login.aspx?d irect $=$ true $\&$ profile $=$ ehost $\&$ scope $=$ site $\&$ a uthtype $=$ crawler $\&$ jrnl $=00131172 \& A N=$ $32708994 \& \mathrm{~h}=$ zefUDSEBKCe4B5sIydry 4bY6yB2AdBswnEK2ugYFJPfPB2wcw 2Y7YwrO8fI\%2BcXOz3O0rywghePSh CctkFjamSw\%3D\%3D\&crl $=\mathrm{c}$

[17] Maria, F., Asikin, M., \& Karomah, N. (2019). Membangun Kemampuan Berpikir Kreatif Matematis Siswa dengan Pembelajaran PjBL terintegrasi Pendekatan STEM. Prosiding Seminar Nasional Pascasarjana 2019, 612-617.

[18] Ng, B. L. L., Liu, W. C., \& Wang, J. C. K. (2016). Student Motivation and Learning in Mathematics and Science: A Cluster Analysis. International Journal of Science and Mathematics Education, 14(7), 1359-1376. https://doi.org/10.1007/s10763-0159654-1

[19] Prismasari, D. I., Hartiwi, A., \& Indrawati. (2019). Science, Technology, Engineering and Mathematics (STEM ) pada Pembelajaran IPA SMP. Seminar Nasional Pendidikan FISIKA, 4(1), 4345.

[20] Rusman. (2012). Pembelajaran berbasis teknologi dan komunikasi. Grafindo.

[21] Sanders, M. (2009). STEM, STEM Education, STEAMMANIA. The Technology Teacher, December/January, 20-26. https://vtechworks.lib.vt.edu/handle/109 $19 / 51616$ 
[22] Snow, C. E., \& Dibner, K. E. (2016). Science Literacy: Concept, Context and Consequences. The National Academic Press.

[23] Srikoom, W., Hanuscin, D., \& Faikhamta, C. (2017). Perceptions of In-Service Teachers toward Teaching STEM in Thailand. Asia-Pacific Forum on Science Learning and Teaching, 18(2). https://search.proquest.com/openview/3a 39a4764311eaf272af3e430a054443/1?p q-origsite $=$ gscholar \&cbl $=2046135$

[24] Triana, D., Anggraito, Y. U., \& Ridlo, S. (2020). Effectiveness of Environmental Change Learning Tools Based on STEMPjBL Towards 4C Skills of Students. Jise, 9(2), 181-187. http://journal.unnes.ac.id/sju/index.php/ji se

[25] Trivena et al. (2018). Fifth-grade elementary school perception of STEM. International Conference on Mathematics and Science Education, 3, 475-480.

[26] Verma, A. K., \& McKinney, S. E. (2011). Engaging students in STEM careers with project based learning - Marinetech project. Technology \& Engineering Teacher, 7(1), 25-32.

[27] Wang, H.-H., Moore, T. J., Roehrig, G. H., \& Park, M. S. (2011). STEM Integration: Teacher Perceptions and Practice STEM Integration: Teacher Perceptions and Practice. Journal of PreCollege Engineering Education Research (J-PEER), 1(2), 1-13. https://doi.org/10.5703/1288284314636

[28] Woolley, M. E., Strutchens, M. E., Gilbert, M. C., \& Martin, W. G. (2010). Mathematics success of black middle school students: Direct and indirect effects of teacher expectations and reform practices. Negro Educational Review, 61(1-4), 41-59. https://www.proquest.com/openview/1c7 e7a0625ccc584a42b0e5c89d8cc93/1?pqorigsite $=$ gscholar $\& \mathrm{cbl}=46710$
[29] Wulandari, N. T., Mulyana, E. H., \& Lidinilla, D. A. M. (2020). Analisis Unsur Art pada Pembelajaran STEAM untuk Anak Usia Dini. Jurnal Pendidikan Guru, 1(3), 135-141.

[30] Zega, A. (2021). Penerapan Model Project Based Learning (PjBL) dalam Mata Kuliah KonstruksiBangunan Pada Mahasiswa Prodi Teknik Bangunan IKIP Gunungsitoli. Edumaspul Jurnal Pendidikan, 5(1), 622-626.

[31] Zollman, A. (2012). Learning for STEM Literacy: STEM Literacy for Learning. School Science and Mathematics, 112(1), 12-19. https://doi.org/10.1111/j.19498594.2012.00101.x

\section{Profil Penulis 1}

Trivena, lahir di Makale pada tanggal 15 Oktober 1993. Memperoleh gelar Sarjana Pendidikan (S.Pd.) pada program studi Pendidikan Guru Sekolah Dasar Universitas Kristen Ind onesia tahun 2015 dan gelar Magister Pendidikan (M.Pd.) pada program studi Pendidikan Dasar Universitas Pendidikan Indonesia tahun 2019. Penulis saat ini merupakan dosen tetap pada program studi PGSD UKI Toraja.

\section{Profil Penulis 2}

Weryanti Laen Langi', lahir di Toraja pada tanggal 25 Juli 1993. Memperoleh gelar Sarjana Pendidikan (S.Pd.) pada program studi Pendidikan Guru Sekolah Dasar Universitas Negeri Makassar tahun 2015 dan gelar Magister Pendidikan (M.Pd.) pada program studi Pendidikan Dasar Universitas Negeri Malang tahun 2018. Penulis saat ini merupakan dosen tetap pada program studi PGSD UKI Toraja. 